\title{
Effective Governance, Female Educational Attainment, Leadership and Healthcare Outcomes
}

\author{
Tannista Banerjee1, Paula Bobrowski², Barry Friedman ${ }^{3}$ \\ ${ }^{1}$ Department of Economics, Auburn University, Auburn, AL, USA \\ ${ }^{2}$ Department of Political Science, Auburn University, Auburn, AL, USA \\ ${ }^{3}$ Organizational Behavior and Human Resource Management, State University of New York at Oswego, Oswego, USA \\ Email: tzb0018@auburn.edu, bobrope@auburn.edu, barry.friedman@oswego.edu
}

How to cite this paper: Banerjee, T., Bobrowski, P. and Friedman, B. (2017) Effective Governance, Female Educational Attainment, Leadership and Healthcare Outcomes. Theoretical Economics Letters, 7, 1223-1232.

https://doi.org/10.4236/tel.2017.75082

Received: June 16, 2017

Accepted: July 28, 2017

Published: July 31, 2017

Copyright $\odot 2017$ by authors and Scientific Research Publishing Inc. This work is licensed under the Creative Commons Attribution International License (CC BY 4.0).

http://creativecommons.org/licenses/by/4.0/

\begin{abstract}
Positive healthcare outcomes are paramount for national competiveness, as a nation's population is among its most valuable assets. This study examines the relationship between national political stability and control of corruption, female educational achievements and national health outcomes. Results show that increases in a nation's political stability and control of corruption affect female educational achievement positively. We also found that improved female educational level is associated with their presence in top firm and parliament positions. Further analysis showed that greater female representation in parliament increases national health standards.
\end{abstract}

\section{Keywords}

Health Outcomes, Political Stability, Female Educational Attainment, National Governance

\section{Introduction}

Positive healthcare outcomes are paramount for national competiveness, as a nation's population is among its most valuable assets. Despite this seemingly obvious observation, few studies have explored the correlates of effective national healthcare outcomes on a macro level across a wide number of countries. Furthermore, few studies have linked the impact of female leadership representation to favorable healthcare outcomes on a global level. A more comprehensive understanding of healthcare outcomes is important for various reasons. First, globalization has increased competiveness among nations for foreign investment. Second, there exists competition for talent as well as capital. Third, nations with 
superior healthcare outcomes are more likely to effectively compete for capital and talent, especially when both are scarce. Concurrently, there is a societal movement for greater female representation in leadership positions. These factors converge with respect to association between greater female representation in leadership positions and effective healthcare outcomes, which is important from both practical and academic perspectives. This paper studies these important relationships among political stability, educational achievement and female leadership in a country.

Organizational diversity is associated with increased financial performance, market share, and innovation [1]. Recent research supports the beneficial impact of corporate board diversity on firm performance [2]-[8]. The compelling rationale often cited for diversity, and particularly top management diversity in the country [7]. The advantage of diversity at top organizational levels is not in dispute; however, the underlying macro conditions associated with diversity remain unclear. For example, the roles that effective governance (e.g., national political stability and the absence of corruption) and educational attainment play in achieving top leadership diversity have not been adequately explored.

\section{World Governance Indicators (2017)}

Scholars, policymakers and aid recipients recognize that good governance is a fundamental ingredient of sustained economic development. This growing understanding spurred policy-relevant indicators of governance and resulted in the development of the Worldwide Governance Indicators [9]. The World Bank and the Brookings Institution assessed the quality of governance in more than 213 countries and territories worldwide. "Governance effectiveness" describes how well the government exercises its powers to create and enforce policies that benefit its citizens. Effective governance is essential to both successful development and maintaining environmental quality and health [9]. To achieve their environmental commitments and goals, nations need strong legislative, diversified political and effective judicial systems [9].

\section{Female Education}

Higher education level attainment is linked to better employment options and increased social supports that together support opportunities for healthier choices. Higher levels of education can lead to a greater sense of control over one's life, which is linked to better health and fewer chronic conditions [10]. Since the Industrial Revolution, the changing nature of women's participation in the labor force has been a critical dimension of the development process. Women's employment is driven by a range of factors, including education, social norms, and economic conditions. Supply and demand dimensions that are important to female upward mobility in labor markets include access to better education and training programs. It is important that young girls remain in school to ensure that they receive a good quality education, thereby increasing their chances of finding decent employment and advancements in the workplace [11].

The association between top leadership diversity and macro healthcare outcomes is unclear. More specifically, the relationships among private or public 
sector top leadership diversity, higher school life expectancy and lower rates have not been adequately explored. These and other healthcare and educational outcomes are significant indictors of national well-being and its citizens, and are therefore worthy of study. We therefore study relationships among these variables.

The paper is organized as follows. We first describe the variable and data in Section 2. Section 3 describes the hypotheses followed by the results in Section 4. Section 5 concludes and presents the limitations of the study.

\section{Variable and Data Description}

We gathered data from different sources for this study.

Political stability: The main variable is the political stability of a country. The political stability is measured by the political stability and the absence of violence/terrorism in a country. This variable measures the perceptions of the likelihood of political instability and/or politically-motivated violence, including terrorism. The measure is available from 2010 to 2015 from World Governance Indicators [12]. The measure ranges from approximately -2.5 (weak) to 2.5 (strong) governance performance. Table A1 in the appendix provides a summary definition of all the variables and summary statistics.

Control of corruption: This measure reflects perceptions of the extent to which public power is exercised for private gain, including both petty and grand forms of corruption, as well as "capture" of the state by elites and private interests. The estimate of governance ranges from approximately -2.5 (weak) to 2.5 (strong) governance performance. We gather the measure from 2010 to 2015 from World Governance Indicators [12].

GDP: Data on Gross Domestic Product in 2010 US dollars is collected from World Bank [13].

FDI: Data on Foreign direct investment in 2010 US dollars is collected from World Bank [13].

Data on female primary education completion rate, female unemployment rate, and proportion of seats held by women in national parliaments are collected from World Bank [13]. Data on all variables are collected from 2010 to 2015.

Female school life expectancy: Female school life expectancy is measured by the average number of years a female child is in the educational system. The data is collected from UNESCO [14] and the variable is available from 2010 to 2015.

Measures of health outcomes: Data on mortality rate and mortality under-five are collected from World Bank [13]. Mortality rate is measured by the number of infants dying before reaching one year of age, per 1000 live births in country. Mortality under-five is measured by the probability per 1000 that a newborn baby will die before reaching age five. Both variables are collected from 2010 to 2015.

\section{Hypotheses}

To achieve better quality of life, commitment toward their citizens, and meet 
their goals, countries need effective political stability and strong judicial systems [9]. We hypothesize that the strong diversified social structures and processes form the foundation upon which economic and environmental progress relies. Literature also shows that higher education gives better control over one's life and better health [10]. Education is also positively related to employment status and progress in the workplace [11]. Therefore, given the literature, we present the following two hypotheses:

H1: Effective governance is positively related to higher female educational attainment.

H2: Increased educational attainment is positively associated with increased female representation in organizational and government positions of influence (i.e., executive, managerial and government positions).

Hypothesis 1 and 2 are tested using the following equation:

$$
Y_{i t}=\alpha_{0}+\alpha_{1} X_{1 i t-1}+\alpha_{2} X_{2 i t-1}+n_{i t}
$$

where $Y_{i t}$ is the primary education completion rate by female as a percentage of relevant age group in country $i$ for year $t . X_{1 i t-1}$ is a vector of variables measuring national governance effectiveness, in country $i$ for year $t-1$. Governance effectiveness for 146 countries is from the WGI indicators, 2010-2015 [12], these countries and years were selected on the basis of data availability. Both developed and developing countries are present in the data, but very small countries where no data is available like Cook Island were not included. The WGI variables [12], control of corruption and political stability, are included in $X_{1 i t-1}$. Control of corruption and political stability were selected on the basis of their availability across countries and lowest correlation between each other. $X_{2 i t-1}$ includes all other country specific controls: per capita Gross Domestic Product (2010 US dollars) (GDP) and foreign direct investment in 2010 US dollars (FDI). Country specific control variables control for unobserved country specific effects in the regression.

Time dummies control for unobserved time specific effects, and we used clustered standard errors, clustered at the country level. Since we control for unobserved time and country specific effects omitted variable bias is not a concern for estimation of Equation (1). Next, we used lagged $X_{1 i t-1}$ and $X_{2 i t-1}$ to control for the endogeneity/reverse causality problem. The timing assumption that primary education completion rate could affect the right hand side variables are avoided by the inclusion of lagged $X_{1 i t-1}$ and $X_{2 i t-1}$. Because lagged $X_{1 i t-1}$ and $X_{2 i t-1}$ have a non-instantaneous impact on $Y_{i t}$ and limits a potential simultaneity bias problem in Equation (1).

We estimated Equation (1) by ordinary-least-square estimation with time fixed and clustered standard errors.

In order to test Hypothesis 2, we estimate the effect of female school life expectancy (SLE) in country $i$ for year $t$ on educational achievements ([13] and [14]). Dependent variables in different specifications are female unemployment rate, increased representation of female in organizational and government positions. 


\section{Health outcomes}

The development of society can be judged by the quality of its population's health and how fairly favorable health outcomes are distributed across the social spectrum. Strengthening health equity globally is central to this premise [11]. Better education and female labor force participation makes economic sense and is justified to thwart gender inequities ([12] and [13]). Low income mothers are more likely than higher income mothers to have pre-term deliveries, low birthweight babies who are at higher risk for chronic diseases, and infants with behavioral problems [12]. Female employment lowers disease risks and may increase health status for all residents [14]. Therefore, our last hypothesis is that:

H3: Increased female representation in leadership positions are positively related to increased health outcomes.

We tested hypothesis 3, replacing $Y_{i t}$ in different specifications with the health outcome of the country. Health outcomes are the infant mortality rate, mortality rate under-five and the life expectancy at birth for country $i$ in year $t$. Infant mortality is the number of infants dying before reaching one year of age, per 1000 live births in country $i$ for year $t$. Under-five mortality rate is the probability per 1000 that a newborn baby will die before reaching age five, if subject to age-specific mortality rates of the specified year. Life expectancy at birth indicates the number of years a newborn infant would live if prevailing patterns of mortality at the time of its birth were to stay the same throughout its life.

\section{Results}

Results of hypotheses testing are presented in Tables 1-6. Table 1 shows the estimation results of Equation (1) when the dependent variable is the primary education completion rate by female as a percentage of relevant age group in country $i$ for year $t$. The second and third columns show that political stability and control of corruption significantly increase female educational achievements (by 9 percentage points and 8 percentage points). When we include both control

Table 1. Effect of political stability and control of corruption (effective governance) on primary education completion rate.

\begin{tabular}{cccc}
\hline & $(1)$ & $(2)$ & $(3)$ \\
VARIABLES & $\begin{array}{c}\text { Primary education } \\
\text { completion rate }\end{array}$ & $\begin{array}{c}\text { Primary education } \\
\text { completion rate }\end{array}$ & $\begin{array}{c}\text { Primary education } \\
\text { completion rate }\end{array}$ \\
Political stability & $0.088^{* * *}(0.014)$ & & $0.0714^{* * *}(0.023)$ \\
Control of corruption & & $0.078^{* * *}(0.013)$ & $0.023(0.021)$ \\
GDP & $4.13 \mathrm{e}-12(2.13 \mathrm{e}-12)$ & $2.84 \mathrm{e}-12(1.87 \mathrm{e}-12)$ & $3.64 \mathrm{e}-12(2.13 \mathrm{e}-12)$ \\
FDI & $5.86 \mathrm{e}-11(7.03 \mathrm{e}-11)$ & $-7.43 \mathrm{e}-13(6.43 \mathrm{e}-11)$ & $3.25 \mathrm{e}-11(7.12 \mathrm{e}-11)$ \\
Year fixed effect & Yes & Yes & Yes \\
Constant & $0.856^{* * *}(1.592)$ & $0.856^{* * *}(1.602)$ & $0.858^{* * *}(1.548)$ \\
Observations & 533 & 533 & 533 \\
R-squared & 0.530 & 0.240 & 0.241 \\
\hline
\end{tabular}

${ }^{* * *},{ }^{* *}$ and $*$ denote $99 \%, 95 \%$ and $90 \%$ level of confidence. 
Table 2. Effect of political stability and control of corruption (effective governance) on primary education completion rate. Fixed effect model.

\begin{tabular}{cccc}
\hline & $(1)$ & $(2)$ & $(3)$ \\
\hline VARIABLES & $\begin{array}{c}\text { Primary education } \\
\text { completion rate }\end{array}$ & $\begin{array}{c}\text { Primary education } \\
\text { completion rate }\end{array}$ & $\begin{array}{c}\text { Primary education } \\
\text { completion rate }\end{array}$ \\
Political stability & $0.039^{* * *}(0.008)$ & & $0.020^{* *}(0.009)$ \\
Control of corruption & & $0.041^{* *}(0.018)$ & $0.041^{* *}(0.018)$ \\
GDP & $4.95 \mathrm{e}-14(2.08 \mathrm{e}-14)$ & $3.97 \mathrm{e}-14(6.73 \mathrm{e}-14)$ & $3.97 \mathrm{e}-14(6.74 \mathrm{e}-14)$ \\
FDI & $1.91 \mathrm{e}-13(2.90 \mathrm{e}-13)$ & $-7.43 \mathrm{e}-13(6.43 \mathrm{e}-11)$ & $1.78 \mathrm{e}-13(2.90 \mathrm{e}-13)$ \\
Year fixed effect & Yes & Yes & Yes \\
Constant & $0.859^{* * *}(0.014)$ & $0.863^{* * *}(0.014)$ & $0.863^{* * *}(0.014)$ \\
Observations & 533 & 533 & 533 \\
R-squared & 0.208 & 0.170 & 0.171 \\
\hline
\end{tabular}

$* * *, * *$ and ${ }^{*}$ denote $99 \%, 95 \%$ and $90 \%$ level of confidence.

Table 3. Effect of political stability and control of corruption (effective governance) on female school life expectancy (SLE). Fixed effect model.

\begin{tabular}{cccc}
\hline & $(1)$ & $(2)$ & $(3)$ \\
\hline VARIABLES & SLE & SLE & SLE \\
Political Stability & $0.719^{* * *}(0.132)$ & & $0.413^{* * *}(0.139)$ \\
Control of corruption & & $1.413^{\star * *}(0.176)$ & $1.232^{\star * *}(0.188)$ \\
GDP & $2.07 \mathrm{e}-13(9.25 \mathrm{e}-14)$ & $1.21 \mathrm{e}-13(9.04 \mathrm{e}-14)$ & $1.28 \mathrm{e}-13(8.94 \mathrm{e}-14)$ \\
FDI & $-3.69 \mathrm{e}-12(1.62 \mathrm{e}-12)$ & $-3.24 \mathrm{e}-12(1.57 \mathrm{e}-12)$ & $-3.48 \mathrm{e}-12(1.58 \mathrm{e}-12)$ \\
Year fixed effect & Yes $^{* *}$ & Yes $^{* *}$ & Yes $^{* *}$ \\
Constant & $13.012^{\star * *}(0.246)$ & $12.928^{* * *}(0.234)$ & $12.978^{\star * *}(0.227)$ \\
Observations & 461 & 461 & 461 \\
R-squared & 0.423 & 0.495 & 0.526 \\
\hline
\end{tabular}

${ }^{* * *},{ }^{* *}$ and $*$ denote $99 \%, 95 \%$ and $90 \%$ level of confidence.

Table 4. Effects of number of years in the school for female (educational achievement) on female unemployment rate, increased representation in organizational and government positions.

\begin{tabular}{cccc}
\hline & $(1)$ & $(2)$ & $(3)$ \\
VARIABLES & Female & Onemployment rate & of Firms with \\
female top manager & $\begin{array}{c}\text { Proportion of seats held } \\
\text { by women in } \\
\text { national parliaments }\end{array}$ \\
SLE & $-0.023(0.071)$ & $0.166^{* * *}$ & $0.188^{* *}(0.088)$ \\
GDP & $-4.26 \mathrm{e}-14(2.53 \mathrm{e}-13)$ & $-4.30 \mathrm{e}-12(5.78 \mathrm{e}-12)$ & $-8.42 \mathrm{e}-13(3.40 \mathrm{e}-13)$ \\
FDI & $-2.43 \mathrm{e}-11^{* * *}(8.54 \mathrm{e}-12)$ & $7.33 \mathrm{e}-11^{*}(2.08 \mathrm{e}-10)$ & $5.09 \mathrm{e}-11^{* * *}(1.68 \mathrm{e}-11)$ \\
Year fixed effect & Yes & Yes & Yes \\
Constant & $12.160^{* *}(5.293)$ & $6.890(5.816)$ & $3.963(6.395)$ \\
Observations & 830 & 853 & 853 \\
R-squared & 0.018 & 0.130 & 0.046 \\
\hline
\end{tabular}

$* * *, * *$ and $*$ denote $99 \%, 95 \%$ and $90 \%$ level of confidence. 
Table 5. Influence of female in parliament on health outcomes. Fixed effect model.

\begin{tabular}{|c|c|c|c|c|}
\hline & (Fixed effect) & (Poisson) & (Fixed effect) & (Poisson) \\
\hline VARIABLES & $\begin{array}{l}\text { Mortality } \\
\text { rate }\end{array}$ & $\begin{array}{l}\text { Mortality } \\
\text { rate }\end{array}$ & $\begin{array}{l}\text { Mortality } \\
\text { under-five }\end{array}$ & $\begin{array}{l}\text { Mortality } \\
\text { under-five }\end{array}$ \\
\hline $\begin{array}{l}\% \text { of Female in } \\
\text { parliaments }\end{array}$ & $\begin{array}{l}-0.133^{* *} \\
(0.062)\end{array}$ & $\begin{array}{l}-0.004^{* * *} \\
(0.001)\end{array}$ & $\begin{array}{l}-0.167^{*} \\
(0.095)\end{array}$ & $\begin{array}{l}-0.003 \\
(0.003)\end{array}$ \\
\hline $\begin{array}{c}\text { Public health } \\
\text { expenditure as } \\
\text { a \% of total health } \\
\text { expenditure }\end{array}$ & $\begin{array}{l}-0.538^{* * *} \\
(0.037)\end{array}$ & & $\begin{array}{l}-0.805^{* * *} \\
(0.057)\end{array}$ & $\begin{array}{c}0.000 \\
(0.001)\end{array}$ \\
\hline $\begin{array}{c}\text { Health expenditure } \\
\text { as a percentage of GDP }\end{array}$ & & $\begin{array}{l}-0.010 \\
(0.011)\end{array}$ & & \\
\hline Year fixed effect & Yes $^{* *}$ & Yes $^{* *}$ & Yes $^{* *}$ & Yes $^{* *}$ \\
\hline GDP & $\begin{array}{c}-1.48 \mathrm{e}-12^{\star *} \\
(6.74 \mathrm{e}-13)\end{array}$ & $\begin{array}{c}-1.00 \mathrm{e}-13^{* * *} \\
(2.70 \mathrm{e}-14)\end{array}$ & $\begin{array}{c}-2.03 e-12^{\star} \\
(1.04 e-12)\end{array}$ & $\begin{array}{c}-1.11 \mathrm{e}-13^{\star * *} \\
(3.50 \mathrm{e}-14)\end{array}$ \\
\hline FDI & $\begin{array}{c}-7.23 \mathrm{e}-11^{\star *} \\
(2.92 \mathrm{e}-11)\end{array}$ & $\begin{array}{l}-1.36 \mathrm{e}-13 \\
(1.83 \mathrm{e}-13)\end{array}$ & $\begin{array}{c}-1.06 \mathrm{e}-10^{\star *} \\
(4.51 \mathrm{e}-11)\end{array}$ & $\begin{array}{l}-1.37 \mathrm{e}-13 \\
(2.35 \mathrm{e}-13)\end{array}$ \\
\hline Constant & $\begin{array}{c}63.039^{* * *} \\
(2.815)\end{array}$ & & $\begin{array}{c}90.361^{* * *} \\
(4.340)\end{array}$ & \\
\hline Observations & 875 & 873 & 875 & 873 \\
\hline Adj R-squared & 0.236 & & 0.221 & \\
\hline Log likelihood & & -1493.591 & & -1649.183 \\
\hline Prob $>$ chi $^{2}$ & & 0.000 & & 0.003 \\
\hline
\end{tabular}

$* * *, * *$ and $*$ denote $99 \%, 95 \%$ and $90 \%$ level of confidence.

Table 6. Influence of female in parliament on health outcomes.

\begin{tabular}{ccc}
\hline VARIABLES & $\begin{array}{c}\text { (Poisson) } \\
\text { Life expectancy }\end{array}$ & $\begin{array}{c}\text { (Fixed effect) } \\
\text { Life expectancy }\end{array}$ \\
\hline $\begin{array}{c}\text { Women in parliaments } \\
\text { Public health expenditure as } \\
\text { a of total health expenditure }\end{array}$ & $0.001^{* * *}(0.001)$ & $0.057^{\star * *}(0.006)$ \\
GDP & $0.001(0.000)$ & $0.012^{* *}(0.005)$ \\
FDI & $3.05 \mathrm{e}-15^{* *}(1.38 \mathrm{e}-15)$ & $-2.39 \mathrm{e}-13^{*}(1.36 \mathrm{e}-13)$ \\
Year fixed effect & $1.26 \mathrm{e}-14^{*}(7.28 \mathrm{e}-15)$ & $-9.54 \mathrm{e}-13^{*}(1.58 \mathrm{e}-12)$ \\
Constant & & Yes \\
Observations & & 851 \\
Adj R-squared & & 0.125 \\
\hline
\end{tabular}

$* * *, * *$ and $*$ denote $99 \%, 95 \%$ and $90 \%$ level of confidence.

of corruption and political stability as independent variables (column 4), only political stability affects female educational achievements significantly, by 7 percentage points.

We next estimated Equation (1) using an error component model where we 
included the individual country specific heterogeneity term. This model controls for unobserved country specific effects along with time specific effects. We estimated this fixed effect model using unconditional maximum likelihood estimation technique. Results are presented in Table 2. We also estimated the random effect model but the random effect model is not consistent given the correlation between individual country components and other explanatory variables. Significant ( $\mathrm{p}$ value varies between 0.001 and 0.05 ). The Hausman specification test also showed the justification of the fixed over the random effect model. Results in Table 2 are qualitatively equivalent to results in Table 1 though the values of estimated coefficients are lower. But our conclusion holds that the political stability and control of corruption significantly increase female educational achievements.

Table 3 presents fixed effect estimations of Equation (1) where $Y_{i t}$ is the female school life expectancy (SLE). SLE data is obtained from UNESCO and is describes as "the average number of years a female child is in the educational system". Results show that both control of corruption and political stability increase SLE significantly.

Next we present the results for Hypothesis 2. We estimate the effect of SLE in country $i$ for year $t$ on educational achievements ([13] and [14]). Dependent variables in different specifications as presented in Table 4 are female unemployment rate, increased representation of female in organizational and government positions. Table 4 shows that the SLE for females increases their presence in top positions of firms ( 2 percentage points) and in parliament by 19 percentage point.

We then tested hypothesis 3 , the influence of female participation in the parliament on the health outcome of the country. Health outcomes are the infant mortality rate, mortality rate under-five and the life expectancy at birth for country $i$ in year $t$. Infant mortality is the number of infants dying before reaching one year of age, per 1000 live births in country $i$ for year $t$. Under-five mortality rate is the probability per 1000 that a newborn baby will die before reaching age five, if subject to age-specific mortality rates of the specified year. Life expectancy at birth indicates the number of years a newborn infant would live if prevailing patterns of mortality at the time of its birth were to stay the same throughout its life.

Fixed effect and Poisson estimation results are presented in Table 5. Results show that the increased presence of female in parliament decreases mortality rate. Column 2 and 4 show that women in parliament has 13 and 16 percentage points negative significant effect on the mortality rate and mortality rate under five. Table 6 presents that the women in parliament have a positive significant effect on life expectancy. We conclude that the increasing presence of female in parliament decreases the mortality rate and increases life expectancy.

\section{Conclusion and Limitations}

This study examined the critical role of political stability in influencing female educational achievements and health outcomes. A detailed country level analysis 
shows that education provides females with greater access to important leadership positions of the country. These greater leadership opportunities facilitate female employment and overall national health outcomes.

The study has several limitations. First, a longer time period and inclusion of more countries could increase the generalizability of the findings. Second, the analyses reported here do not allow for cause and effect statements. Longitudinal studies may move our understanding of the causal relationships among female leadership, education and health outcomes ahead.

Despite these limitations, the authors hope that the research reported here stimulates further study. For example, which career fields for women most influence health outcomes? We studied management, leadership and government positions, but are there other professions or occupations that have positive impact on health outcomes?

More research is needed with respect to the specific causal pathways among government effectiveness, female efficacy, and health outcomes. Identifying the links among these and other variables with health improve health worldwide and to narrow the health outcome gap among countries.

\section{References}

[1] Lynch, J., Smith, G.D., Harper, S. and Hillemeier, M. (2004) Is Income Inequality a Determinant of Population Health? Part 2. US National and Regional Trends in Income Inequality and Age- and Cause-Specific Mortality. Milbank Quarterly, 82, 355-400. https://doi.org/10.1111/j.0887-378X.2004.00312.x

[2] Richard, O.C. (2000) Racial Diversity, Business Strategy, and Firm Performance: A Resource-Based View. Academy of Management Journal, 43, 164-177. https://doi.org/10.2307/1556374

[3] Erhardt, N.L., Werbel, J.D. and Shrader, C.B. (2003) Board of Director Diversity and Firm Financial Performance. Corporate Governance: An International Review, 11, 102-111. https://doi.org/10.1111/1467-8683.00011

[4] Campbell, K. and Mínguez-Vera, A. (2008) Gender Diversity in the Boardroom and Firm Financial Performance. Journal of Business Ethics, 83, 435-451. https://doi.org/10.1007/s10551-007-9630-y

[5] Roberson, Q., Holmes, O. and Perry, J. (2017) Transforming Research on Diversity and Firm Performance: A Dynamic Capabilities Perspective. Academy of Management Annals, 11, 189-216. https://doi.org/10.5465/annals.2014.0019

[6] Zahra, S. and Pearce, J. (1989) Boards of Directors and Corporate Financial Performance: A Review and Integrative Model. Journal of Management, 15, 291-334. https://doi.org/10.1177/014920638901500208

[7] Zhang, L. (2012) Board Demographic Diversity, Independence, Corporate Social Performance. Corporate Governance: The International Journal of Business in Society, 12, 686-700. https://doi.org/10.1108/14720701211275604

[8] Rhode, D.L. and Packel, A.K. (2014) Diversity on Corporate Boards: How Much Difference Does Difference Make? The Delaware Journal of Corporate Law, 39, 377-426.

[9] Kaufmann, D., Kraay, A. and Mastruzzi, M. (2011) The Worldwide Governance Indicators: Methodology and Analytical Issues. Hague Journal on the Rule of Law, 3, 220-246. https://doi.org/10.1017/S1876404511200046 
[10] Adler, N.E. and Newman, K. (2002) Socioeconomic Disparities in Health: Pathways and Policies. Health Affairs, 21, 60-76. https://doi.org/10.1377/hlthaff.21.2.60

[11] Verick, S. (2014) Female Labor Force Participation in Developing Countries. IZA World of Labor, 2014, 87. https://doi.org/10.15185/izawol.87

[12] World Governance Indicators (2017). http://info.worldbank.org/governance/wgi/index.aspx\#home

[13] World Bank (2017). http://data.worldbank.org/indicator

[14] United Nations (2017). https://genderstats.un.org/\#/home

Table A1. Definition and summary statistics of main variables.

\begin{tabular}{|c|c|c|c|}
\hline Variables & Definition and source & Mean & $\begin{array}{l}\text { Standard } \\
\text { Deviation }\end{array}$ \\
\hline Political stability & $\begin{array}{l}\text { Political Stability and Absence of } \\
\text { Violence/Terrorism measures perceptions } \\
\text { of the likelihood of political instability } \\
\text { and/or politically-motivated violence, } \\
\text { including terrorism. Ranges from } \\
\text { approximately }-2.5 \text { (weak) to } 2.5 \text { (strong) } \\
\text { governance performance. (WGI Indicators) }\end{array}$ & $-4.11 \mathrm{e}-10$ & 0.998 \\
\hline $\begin{array}{l}\text { Control of } \\
\text { corruption }\end{array}$ & $\begin{array}{l}\text { Reflects perceptions of the extent to which } \\
\text { public power is exercised for private gain, } \\
\text { including both petty and grand forms of } \\
\text { corruption, as well as "capture" of the state by } \\
\text { elites and private interests. Estimate of } \\
\text { governance (ranges from approximately } \\
-2.5 \text { (weak) to } 2.5 \text { (strong) governance } \\
\text { performance) (WGI Indicators [12]) }\end{array}$ & $1.02 \mathrm{e}-09$ & 0.998 \\
\hline $\begin{array}{l}\text { Gross Domestic } \\
\text { Product }\end{array}$ & $\begin{array}{l}\text { Gross Domestic Product in } 2010 \text { US dollars. } \\
\text { (Source: World Bank [13]). }\end{array}$ & $3.80 \mathrm{e}+11$ & $1.45 e+12$ \\
\hline $\begin{array}{l}\text { Foreign Domestic } \\
\quad \text { Investment }\end{array}$ & $\begin{array}{l}\text { Foreign direct investment in } 2010 \text { US dollars. } \\
\text { (Source: World Bank [13]). }\end{array}$ & $9.78 \mathrm{e}+09$ & $3.41 \mathrm{e}+10$ \\
\hline $\begin{array}{c}\text { Primary education } \\
\text { completion rate (female) }\end{array}$ & Source: World Bank [13] & 13.95936 & 3.315795 \\
\hline $\begin{array}{l}\text { Female school } \\
\text { life expectancy }\end{array}$ & $\begin{array}{l}\text { The average number of years a } \\
\text { female child is in the educational } \\
\text { system (Source: UNESCO [14]) }\end{array}$ & 73.09732 & 9.320947 \\
\hline $\begin{array}{c}\text { Female } \\
\text { Unemployment Rate }\end{array}$ & Source: World Bank [13] & 10.19942 & 7.628224 \\
\hline $\begin{array}{l}\text { Proportion of seats } \\
\text { held by women in } \\
\text { national parliaments }\end{array}$ & Source: World Bank [13] & 19.24659 & 11.65458 \\
\hline Mortality rate & $\begin{array}{l}\text { Number of infants dying before reaching } \\
\text { one year of age, per } 1000 \text { live births in } \\
\text { country (Source: World Bank [13]). }\end{array}$ & 25.95855 & 23.77791 \\
\hline $\begin{array}{l}\text { Mortality } \\
\text { under-five }\end{array}$ & $\begin{array}{l}\text { Probability per } 1000 \text { that a newborn } \\
\text { baby will die before reaching } \\
\text { age five (Source: World Bank [13]). }\end{array}$ & 35.22216 & 36.41165 \\
\hline
\end{tabular}


Submit or recommend next manuscript to SCIRP and we will provide best service for you:

Accepting pre-submission inquiries through Email, Facebook, LinkedIn, Twitter, etc. A wide selection of journals (inclusive of 9 subjects, more than 200 journals)

Providing 24-hour high-quality service

User-friendly online submission system

Fair and swift peer-review system

Efficient typesetting and proofreading procedure

Display of the result of downloads and visits, as well as the number of cited articles Maximum dissemination of your research work

Submit your manuscript at: http://papersubmission.scirp.org/

Or contact tel@scirp.org 